\title{
A G-Protein-Coupled Estrogen Receptor Is Involved in Hypothalamic Control of Energy Homeostasis
}

\author{
Jian Qiu, ${ }^{1}$ Martha A. Bosch, ${ }^{1}$ Sandra C. Tobias, ${ }^{3}$ Andree Krust, ${ }^{5}$ Sharon M. Graham, ${ }^{2}$ Stephanie J. Murphy, ${ }^{2}$ \\ Kenneth S. Korach, ${ }^{4}$ Pierre Chambon, ${ }^{5}$ Thomas S. Scanlan, ${ }^{3}$ Oline K. Rønnekleiv, ${ }^{1}$ and Martin J. Kelly ${ }^{1}$ \\ Departments of ${ }^{1}$ Physiology and Pharmacology and ${ }^{2}$ Anesthesiology and Perioperative Medicine, Oregon Health and Science University, Portland, Oregon \\ 97239-3098, ${ }^{3}$ Departments of Pharmaceutical Chemistry and Cellular and Molecular Pharmacology, University of California, San Francisco, San Francisco, \\ California 94143, ${ }^{4}$ Laboratory of Reproductive and Developmental Toxicology, National Institutes of Health, Research Triangle Park, North Carolina 27709, \\ and ${ }^{5}$ Institute de Genetique et de Biologie Moleculaire et Cellulaire, Centre National de la Recherche Scientifique /Institut National de la Santé et de la \\ Recherche Médicale, Université Louis Pasteur, College de France, 67404 Illkirch-Cedex, France
}

Estrogens are involved in the hypothalamic control of multiple homeostatic functions including reproduction, stress responses, energy metabolism, sleep cycles, temperature regulation, and motivated behaviors. The critical role of $17 \beta$-estradiol $\left(\mathrm{E}_{2}\right)$ is evident in hypoestrogenic states (e.g., postmenopause) in which many of these functions go awry. The actions of $\mathrm{E}_{2}$ in the brain have been attributed to the activation of estrogen receptors $\alpha$ and $\beta$ through nuclear, cytoplasmic, or membrane actions. However, we have identified a putative membrane-associated estrogen receptor that is coupled to desensitization of $\mathrm{GABA}_{\mathrm{B}}$ and $\mu$-opioid receptors in guinea pig and mouse hypothalamic proopiomelanocortin neurons. We have synthesized a new nonsteroidal compound, STX, which selectively targets the G $\alpha$ q-coupled phospholipase C-protein kinase C-protein kinase A pathway, and have established that STX is more potent than $\mathrm{E}_{2}$ in mediating this desensitization in an ICI 182, 780-sensitive manner in both guinea pig and mouse neurons. Both $\mathrm{E}_{2}$ and STX were fully efficacious in estrogen receptor $\alpha, \beta$ knock-out mice. Moreover, in vivo treatment with STX, similar to $\mathrm{E}_{2}$, attenuated the weight gain in hypoestrogenic female guinea pigs. Therefore, this membrane-delimited signaling pathway plays a critical role in the control of energy homeostasis and may provide a novel therapeutic target for treatment of postmenopausal symptoms and eating disorders in females.

Key words: GPCR; body weight; $\mathrm{GABA}_{\mathrm{B}}$ receptor; intracellular signaling; potassium channels; POMC neurons

\section{Introduction}

The hypothalamus controls multiple homeostatic functions that change dramatically during the ovulatory cycle and especially during pregnancy and menopause. Fluctuations in circulating estrogens are thought to be responsible for these changes (Komesaroff et al., 1999; Milewicz et al., 2001; Sherwin, 2002; Stearns et al., 2002). The hypothalamic proopiomelanocortin (POMC) neurons are critical neurons in the hypothalamic circuits controlling energy homeostasis (Cone, 2005; Murphy and Bloom, 2005). POMC neurons through direct synaptic contacts modulate the excitability of hypothalamic neurons that control appetite, fluid balance, temperature, stress and reproduction (Horvath, 2005). In addition, POMC neurons project to other brain areas (e.g., midbrain) to control motivated behaviors such as sex and food consumption (Koob, 1992). Although many of the actions of estrogen

Received Jan. 24, 2006; revised April 12, 2006; accepted April 14, 2006.

This work was supported by United States Public Health Service Grants NS43330, NS38809, NS49210, DK68098, and DK57574. We recognize the help of Dr. Emilie F. Rissman (University of Virginia, Charlottesville, VA) in establishing the transgenic mouse colonies.

Correspondence should be addressed to either Dr. Martin J. Kelly or Dr. Oline K. Rønnekleiv, Department of Physiology and Pharmacology, L334, Oregon Health and Science University, Portland, OR 97239-3098. E-mail: kellym@ohsu.edu or ronnekle@ohsu.edu.

DOI:10.1523/JNEUROSCI.0327-06.2006

Copyright $\odot 2006$ Society for Neuroscience $\quad$ 0270-6474/06/265649-07\$15.00/0 are mediated at the level of the hypothalamus, the cellular targets and signaling cascades involved in the effects of estrogen on homeostatic functions remain unclear.

Until recently, the actions of estrogen in the hypothalamus and other brain areas have been attributed to the activation of estrogen receptor $\alpha(\mathrm{ER} \alpha)$ or ER $\beta$ (McEwen and Alves, 1999; Toran-Allerand et al., 1999; Kelly and Levin, 2001; Rønnekleiv and Kelly, 2005). However, we have identified a putative membrane-associated estrogen receptor (mER) that is $\mathrm{G}_{\mathrm{q}}$ coupled to a phospholipase $\mathrm{C}$-protein kinase $\mathrm{C}$-protein kinase A (PLC-PKC-PKA) pathway (Lagrange et al., 1997; Qiu et al., 2003). The activation of this pathway by $E_{2}$ can rapidly disinhibit female POMC neurons through desensitizing $\mu$-opioid and $\mathrm{GABA}_{\mathrm{B}}$ receptors in POMC neurons. We hypothesize that this $\mathrm{mER}$ signaling pathway is involved in heterologous desensitization of $\mu$-opioid and $\mathrm{GABA}_{\mathrm{B}}$ in hypothalamic neurons similar to neurotransmitters like serotonin. Presently, we have characterized the signaling of a nonsteroidal compound, STX, that specifically targets the G-proteincoupled signaling pathway in both male and female hypothalamic POMC neurons. Furthermore, we have established that $\mathrm{E}_{2}$ and STX are fully efficacious in estrogen receptor knockout (KO) mice. Finally, we show that STX, similar to estrogen, regulates homeostatic functions (e.g., energy metabolism) in ovariectomized (hypoestrogenic) females. 


\section{Materials and Methods}

Animals and treatments. All animal procedures described in this study are in accordance with institutional guidelines based on National Institutes of Health standards. Female Topeka guinea pigs (400-600 g), bred in our institutional breeding facility, and female multicolor guinea pigs (400-500 g; Elm Hill Breeding Labs, Chelmsford, MA) were used in these experiments. The guinea pigs were maintained under constant temperature $\left(26^{\circ} \mathrm{C}\right)$ and light (on between 6:30 A.M. and 8:30 P.M.). Animals were housed individually, with food and water provided ad libitum. They were gonadectomized under ketamine-xylazine anesthesia (33 and $6 \mathrm{mg} / \mathrm{kg}$, respectively, s.c.) 5-7 d before experimentation, and they were given sesame oil vehicle $(0.1 \mathrm{ml}$, s.c.) $24 \mathrm{~h}$ before experimentation. Serum estrogen concentrations were measured in the ovariectomized females by radioimmunoassay (Oregon National Primate Research Center Radioimmunoassay Core, Portland, OR) from trunk blood collected on the day of experimentation and were $<10 \mathrm{pg} / \mathrm{ml}$. An additional group of animals were ovariectomized and, after 1 week, were injected with oil vehicle or estradiol benzoate ( $8 \mu \mathrm{g} / \mathrm{kg}$ in oil; $n=6)$ or STX (2 $\mathrm{mg} / \mathrm{kg}$ in oil; $n=4$ ) every other day, 3 times/week for 4 weeks. On completion of the experiments, the uterine weights were obtained.

Wild-type (WT) C57BL/6 mice in these studies were obtained from The Jackson Laboratory (Bar Harbor, ME). ER $\alpha \mathrm{KO}$ (from P. Chambon; C57BL/6) mice were generated from breeding pairs heterozygous for the disrupted $\mathrm{ER} \alpha$ gene, and offspring were screened by PCR amplification of tail DNA using primers as described previously (Dupont et al., 2000). The ER $\alpha \beta$ (double) knock-out (from P. Chambon; C57BL/6) mice were generated from breeding pairs heterozygous for the disrupted $\operatorname{ER} \alpha$ and $\operatorname{ER} \beta$ genes as described previously (Dupont et al., 2000). ER $\beta$ KO (from K. S. Korach; C57BL/6) mice were generated from breeding pairs heterozygous for the disrupted $\operatorname{ER} \beta$ gene as described previously (Krege et al., 1998). Offspring were screened with two sets of primers: the first primer pair (5'ACATCCATACACCCCCACTCAACC $3^{\prime}$ and 5'AAAGAAACATGTCCTGGCAAATCA $3^{\prime}$ ) produced a $600 \mathrm{bp}$ product for the WT allele and no product for the KO allele. The second primer pair ( $5^{\prime} \mathrm{TTCT}-$ GAGGGATCCGCTGTAAG $3^{\prime}$ and 5'AGGCTGCTGATCTCGTTCT $3^{\prime}$ ) produced a $450 \mathrm{bp}$ product for the $\mathrm{KO}$ allele and no product for the WT allele. In addition, hypothalamic slices from WT and $\mathrm{KO}$ mice were tested for immunoreactive ER $\alpha$ using the C1355 antibody kindly provided by Dr. Margaret Shupnik (University of Virginia, Charlottesville, VA). With this antibody we found a high concentration of $\mathrm{ER} \alpha$-immunoreactive neurons in the hypothalamus from WT and $\mathrm{ER} \beta \mathrm{KO}$, but no stain in the $\mathrm{ER} \alpha \mathrm{KO}$ or the $\mathrm{ER} \alpha \beta \mathrm{KO}$ animals. $\mathrm{ER} \beta$ expression was tested using reverse transcription (RT)-PCR of hypothalamic RNA with primer pairs designed to flank the neomycin-resistance gene insert in exon 3 of the ER $\beta$ KO mice (Krege et al., 1998) (forward primer $830-848$ bp and reverse primer 950-968 bp; GenBank accession number NM_207707). These primers produced a PCR product in WT, heterozygous, and $\mathrm{ER} \alpha \mathrm{KO}$ mice but not in $\mathrm{ER} \beta \mathrm{KO}$ mice. All animals were maintained under controlled temperature $\left(25^{\circ} \mathrm{C}\right)$ and photoperiod conditions ( $12 \mathrm{~h} \mathrm{light/dark}$ cycle; lights on between 6:00 A.M. and 6:00 P.M.) with food and water ad libitum. Adult female mice were ovariectomized under ketamine-xylazine anesthesia ( $10 \mathrm{mg} / \mathrm{kg}$, each, i.p.) and allowed to recover for 1 week. Adult male $\mathrm{ER} \alpha \beta \mathrm{KO}$ mice were only available for these studies, and they were not gonadectomized because we found that gonad-intact males responded to E2 and STX.
Therefore, we decided not to do the invasive surgery in these extremely valuable animals.

Drugs. The preparation and concentrations of the drugs for this study have been published (Qiu et al., 2003), with the exception of STX, which was prepared by chemical synthesis via a procedure that has been reported previously (Tobias et al., 2006).

Electrophysiology. Female adult Topeka guinea pigs or adult mice were gonadectomized 6-10 d before each experiment. Hypothalamic slices were prepared and whole-cell recordings were done as described previously (Qiu et al., 2003). The mean resting membrane potential (RMP) for female guinea pig neurons was $-55.3 \pm 0.7 \mathrm{mV}(n=97)$. For the C57BL/6 background mice, the RMP was $-53.0 \pm 1.0 \mathrm{mV}(n=37)$ for wild-type; $-53.4 \pm$ $1.2 \mathrm{mV}(n=25)$ for $\mathrm{ER} \alpha \mathrm{KO} ;-52.2 \pm 1.5 \mathrm{mV}(n=17)$ for $\mathrm{ER} \beta \mathrm{KO}$; and $-55.9 \pm 1.2 \mathrm{mV}(n=24)$ for intact male $\mathrm{ER} \alpha \beta \mathrm{KO}$ mice. The mean input resistance $\left(R_{\mathrm{in}}\right)$ for the female guinea pig arcuate neurons was $610 \pm 50 \mathrm{M} \Omega$ but was greater for the smaller mouse arcuate neurons $(860 \pm 60 \mathrm{M} \Omega)$. There was no difference in the baclofen $\left(\mathrm{EC}_{50}\right)$-induced outward $\mathrm{K}^{+}$current between the guinea pig $(24.5 \pm 1.1 \mathrm{pA} ; n=97)$ and mouse (wild-type, $23.4 \pm$ $4.0 \mathrm{pA}, n=20$; $\mathrm{ER} \alpha \mathrm{KO}, 25.1 \pm 2.4 \mathrm{pA}, n=14$; $\mathrm{ER} \beta \mathrm{KO}, 23.4 \pm$ $3.5 \mathrm{pA}, n=15$; ER $\alpha \beta \mathrm{KO}, 21.6 \pm 1.9 \mathrm{pA}, n=22$ ) experimental groups, and only cells that gave a reversible baclofen response of at least $10 \mathrm{pA}$ were included in the study.

Composite dose-response curves were generated from the following logistic equation fitted by computer (Origin 4.1; Microcal $)$ to the data: $\Delta I \max =100 \times\left([\text { agonist }]^{n} /\left([\text { agonist }]^{n}+\right.\right.$ $\left.\left.\mathrm{EC}_{50}{ }^{\mathrm{n}}\right)\right)$, where $\Delta I \max$ is the maximum outward current for a given agonist, $\mathrm{EC}_{50}$ represents the agonist potency, and $n$ is the Hill slope.

Immunocytochemistry. After electrical recording, the slices were prepared for fluorescence immunocytochemistry as described previously (Qiu et al., 2003).

Statistical analyses. Comparisons between groups were performed using a one-way or two-way ANOVA (with post hoc Newman-Keuls paired analysis). Differences were considered statistically significant if the probability of error was $<5 \%$.

\section{Results}

STX is more potent than $E_{2}$ to attenuate the $\mathrm{GABA}_{\mathrm{B}}$ response Estrogen rapidly reduces the potency of the $G_{A B A}$ receptor agonist baclofen to activate $\mathrm{G}$-protein-coupled, inwardly rectifying $\mathrm{K}^{+}$(GIRK) channels in hypothalamic neurons (Lagrange et al., 1994, 1996, 1997; Kelly et al., 1999; Qiu et al., 2003). These effects are mimicked by the membrane impermeant E2-BSA, suggesting that $\mathrm{E}_{2}$ signals through a membrane receptor (Qiu et al., 2003). Presently, we compared the potency and efficacy of $E_{2}$ and a new diphenylacrylamide compound STX that does not bind to ER $\alpha$ or ER $\beta$ (Qiu et al., 2003) using whole-cell patch recording in hypothalamic arcuate neurons in slices prepared from ovariectomized female guinea pigs. Seventy-five percent of these neurons responded to $\mathrm{E}_{2}$ or STX $(n=67)$, including all of the $\beta$-endorphin identified (POMC) neurons $(n=27)$. For measuring $\mathrm{E}_{2}$ or STX modulation of the $\mathrm{GABA}_{\mathrm{B}}$ response, we used an $\mathrm{EC}_{50}$ concentration $(5 \mu \mathrm{M})$ of baclofen and a protocol in which a densensitization of the response with multiple applications of baclofen was not observed (Qiu et al., 2003). Baclofen induced a robust outward current that subsided after washout, and the application of baclofen $\sim 20 \mathrm{~min}$ later elicited the same robust response. However, if $\mathrm{E}_{2}$ or STX was applied during the interim period (i.e., after the washout of the first application of baclofen), there was a significant $(p<0.005)$ decrease of $>40 \%$ in the response to a second application of baclofen (Fig. 1). Concentration-response 

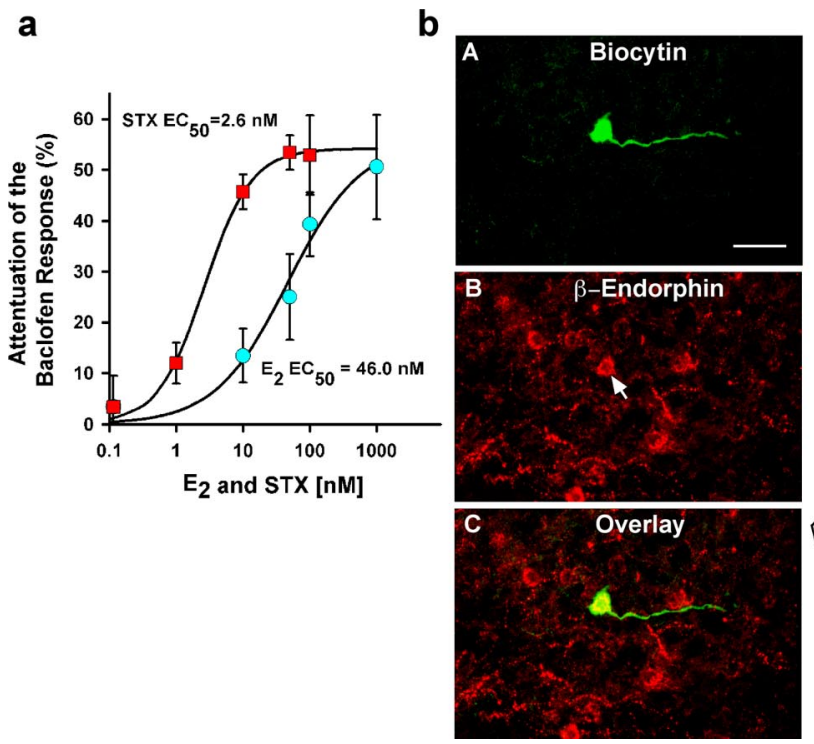

C

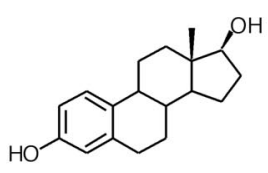

17- $\beta$-estradiol

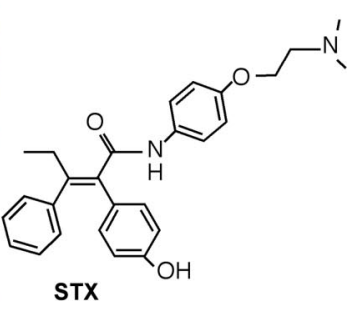

Figure 1. Composite dose-response curves for $\mathrm{E}_{2}$ and STX illustrating the difference in potency between $\mathrm{E}_{2}$ and STX in arcuate POMC neurons. $\boldsymbol{a}$, Experiments were conducted as described in Materials and Methods. Cells were perfused with different concentrations of $E_{2}(0,10,50,100$, and $1000 \mathrm{~nm})$ or STX $(0,1,10,50$, and $100 \mathrm{nM})$. Data are presented as mean $\pm \operatorname{SEM}(n=4-11$ cells/data point). Based on a logistics equation fit to the data points (see Materials and Methods), the $\mathrm{EC}_{50}$ for STX was $2.6 \mathrm{~nm}$, which is 17-fold lower than that found for $E_{2}(46.0 \mathrm{~nm})$. The Hill slope for $E_{2}$ and STX was 0.80 and 1.24, respectively. $\boldsymbol{b}, \boldsymbol{A}$ Biocytin-streptavidin-Cy2 labeling of a small pyramidal arcuate neuron that responded to STX. $\boldsymbol{B}$, Immunocytochemical staining of $\beta$-endorphin in the same neuron (arrow). $\boldsymbol{C}, 0$ verlay of $\boldsymbol{A}$ and $\boldsymbol{B}$. Forty percent of the neurons $(n=49)$ were identified as POMC neurons. Scale bar: $A-C, 20 \mu$ m. C, The chemical structures of $17-\beta$-estradiol $\left(E_{2}\right)$ and the diphenylacrylamide STX.

curves showed that $E_{2}$ and STX rapidly attenuate the $\mathrm{GABA}_{\mathrm{B}}$ response in a concentration-dependent manner with 50\% inhibition at $46.0 \mathrm{~nm}$ for $\mathrm{E}_{2}$ and at $2.6 \mathrm{~nm}$ for STX, which was equally as efficacious as estrogen. Therefore, STX is $\sim 20$ times more potent than $\mathrm{E}_{2}$ in desensitizing the $\mathrm{GABA}_{\mathrm{B}}$ response in hypothalamic arcuate neurons.

To determine whether the response to STX could be blocked with an estrogen receptor antagonist, we used ICI 182,780 (ICI) $(1 \mu \mathrm{M})$ to antagonize the inhibitory effects of STX on the baclofen response. Indeed, ICI 182,780 when coperfused with STX blocked the effects of STX (Fig. 2). Treatment with ICI 182,780 alone had no effect on the baclofen response (Fig. 2). Therefore, these data are consistent with a high-affinity membrane receptor that can bind both estrogen and STX.

\section{Desensitization of the $\mathrm{GABA}_{\mathrm{B}}$ response by STX involves protein kinase $\mathrm{A}$ and $\mathrm{PKC} \delta$}

Previously, we reported that the membrane estrogen receptor in arcuate (POMC) neurons is $\mathrm{G} \alpha_{\mathrm{q}}$-coupled to activation of phospholipase $\mathrm{C}$, leading to the upregulation of protein kinase $\mathrm{C} \delta$ and protein kinase A activity in arcuate (POMC) neurons (Qiu et al., 2003). Therefore, we explored whether STX utilizes the same pathway to desensitize the $\mathrm{GABA}_{\mathrm{B}}$ receptor-mediated response. If activation of the PKA or PKC pathway is involved, inhibition of PKA and/or PKC activity should abrogate the effects of STX on $\mathrm{GABA}_{\mathrm{B}}$ responses. As shown in Figure 2, when we dialyzed neurons with a selective PKA inhibitor, the nonhydrolyzable cAMP analog Rp-cAMPS, the STX-induced reduction of the $\mathrm{GABA}_{\mathrm{B}}$ response was abolished. These results indicate that the suppression of the $\mathrm{GABA}_{\mathrm{B}}$ response by STX requires the activation of PKA. Furthermore, activation of PKC is also critical for STX modulation of the $\mathrm{GABA}_{\mathrm{B}}$ response. Treatment of neurons with bisindolymaleimide (BIS), a broad-spectrum inhibitor of PKC, eliminated the effects of STX (Fig. 2). In addition, the selective
PKC $\delta$ inhibitor rottlerin completely blocked the ability of STX to inhibit the $\mathrm{GABA}_{\mathrm{B}}$ response in hypothalamic neurons, whereas a selective inhibitor of the conventional PKC isoforms, Gö6976, did not attenuate the effects of STX. Altogether, these data indicate that STX and $\mathrm{E}_{2}$ are signaling via the same $\mathrm{mER}$ that is coupled to a $\mathrm{G} \alpha_{\mathrm{q}}-\mathrm{PKC}-\mathrm{PKA}$ pathway. In fact, the effects of estrogen and STX were nonadditive such that coperfusion of both drugs did not generate a greater response $(\mathrm{R} 2 / \mathrm{R} 1=58.1 \pm 2.7 \% ; n=4)$.

\section{$E_{2}$ and STX are fully efficacious in $\mathrm{ER} \alpha \mathrm{KO}, \mathrm{ER} \boldsymbol{\beta} \mathrm{KO}$, and $\mathrm{ER} \boldsymbol{\alpha} \boldsymbol{\beta} \mathrm{KO}$ mice}

As described previously by Blaustein (1994), ER $\alpha$ is abundantly expressed in guinea pig arcuate neurons. Also, ER $\beta$ mRNA and protein are expressed in the rodent arcuate nucleus but to a much lesser extent than $\mathrm{ER} \alpha$ (Shughrue et al., 1997; Fodor and Delemarre-van de Waal, 2001). Therefore, to verify that neither $\mathrm{ER} \alpha$ nor $\mathrm{ER} \beta$ are involved in the rapid desensitization of the $\mathrm{GABA}_{\mathrm{B}}$ response by estrogen, we compared the effects of $\mathrm{E}_{2}$ and STX on the $\mathrm{GABA}_{\mathrm{B}}$ response in arcuate neurons including POMC neurons from $\mathrm{ER} \alpha$ knock-out, $\mathrm{ER} \beta$ knock-out, and wild-type (C57BL/6) mice (Fig. 3). As observed in ovariectomized female guinea pigs, we found that both STX and $E_{2}$ significantly attenuated the $\mathrm{GABA}_{B}$ response in arcuate neurons from ovariectomized $\mathrm{ER} \alpha \mathrm{KO}$ and $\mathrm{ER} \beta \mathrm{KO}$ female and $\mathrm{ER} \alpha \beta \mathrm{KO}$ male mice. Moreover, the efficacy of the response was equivalent in wild-type $(\mathrm{C} 57 \mathrm{BL} / 6)$ and $\mathrm{KO}$ mice, indicating that the effects of STX and $\mathrm{E}_{2}$ are mediated by a membrane $\mathrm{ER}$ (mER) distinct from $\mathrm{ER} \alpha$ or $\mathrm{ER} \beta$ (Fig. 3).

\section{$E_{2}$ and STX prevent excess body weight gain after ovariectomy in guinea pigs}

Evidence from several species indicates that food intake and body weight are influenced both by changes in endogenous estrogens and by exogenous estrogenic treatments (Czaja and Goy, 1975). Butera and Czaja (1984) have shown that the anorexigenic effects of estrogen are attributable to the direct actions of the steroid in the arcuate-ventromedial hypothalamic nuclei. Therefore, we compared the efficacy of STX and $\mathrm{E}_{2}$ in attenuating the weight gain in guinea pigs after ovariectomy (Fig. 4). Female guinea pigs were ovariectomized and allowed to recover for $7 \mathrm{~d}$, at which time they received subcutaneous injections of estradiol benzoate ( 8 $\mu \mathrm{g} / \mathrm{kg})$, STX $(2 \mathrm{mg} / \mathrm{kg})$, or a sesame oil vehicle $(0.1 \mathrm{ml})$ every other day, three times per week for 4 weeks. The body weights were measured before each injection. We found that $E_{2}$ treatment significantly decreased body weight, which is similar to previous reports on the effect of subcutaneous $\mathrm{E}_{2}$ treatment in ovariectiomized females (Fig. 4a) (Czaja and Goy, 1975). As expected, estradiol benzoate significantly increased uterine weight (Fig. 4c) (EB: $2.87 \pm 0.25 \mathrm{~g}$ vs oil: $0.37 \pm 0.08 \mathrm{~g} ; p<0.001$ ). STX also attenuated the body weight gain after ovariectomy (Fig. $4 b$ ). However, unlike estradiol benzoate, STX, as shown previously in the mouse (Qiu et al., 2003), did not increase uterine weight (STX: $0.23 \pm 0.02$ g vs oil: $0.28 \pm 0.03 \mathrm{~g} ; p>0.05$ ). Therefore, the nonsteroidal STX, which is selective for the G-protein-coupled 
estrogen receptor, can mimic the effects of estrogen to alter energy metabolism in females but not the proliferative effects on peripheral reproductive organs.

\section{Discussion}

For the first time we have identified a nonsteroidal compound, STX, which selectively targets the mER and is more potent than $\mathrm{E}_{2}$ in activating a membrane delimited pathway in hypothalamic arcuate neurons. STX is fully efficacious in $\mathrm{ER} \alpha$ and $\operatorname{ER} \beta$ knock-out mice and has no proliferative effects on reproductive organs, yet it is effective in reducing the weight gain associated with hypoestrogenic states. Although we found that other arcuate neurons express this mER signaling pathway (Qiu et al., 2003), this pathway is involved in heterologous desensitization of the $\mu$-opioid (autoreceptor) and $\mathrm{GABA}_{\mathrm{B}}$ receptors in POMC neurons and therefore would play a critical role in dictating the level of excitability POMC neurons. These neurons appear to be the critical "relay" neurons in the melanocortin pathway, and their activity ultimately dictates the level of excitability in feeding circuits (Saper et al., 2002; Jobst et al., 2004; Cone, 2005).

Presently, we have characterized an $\mathrm{mER}$ that is $\mathrm{G}_{\mathrm{q}}$-coupled to a PLC-PKC-PKA pathway using STX as a ligand. This mER has subnanomolar affinity for estrogen based on our previous pharmacological (Schild) analysis (Lagrange et al., 1997). However, STX is a more selective ligand with even greater affinity $(\sim 20-$ fold) for the mER. The activation of this pathway by $E_{2}$ and STX disinhibits female arcuate neurons by uncoupling $\mathrm{GABA}_{\mathrm{B}}$ receptors from downstream $\mathrm{K}^{+}$channels. Also, $\mathrm{E}_{2}$ attenuates the coupling of $\mu$-opioid receptors, which are autoreceptors in POMC neurons, to the same population of $\mathrm{K}^{+}$channels (Kelly et al., 1992; Lagrange et al., 1994, 1997). Therefore, the desensitization of both $\mathrm{GABA}_{\mathrm{B}}$ and $\mu$-opioid receptors by activation of this $\mathrm{mER}$ signaling pathway has the potential to affect synaptic transmission not only in POMC neurons but also in other hypothalamic neurons. Indeed, we also identified this $\mathrm{mER}$ in dopamine neurons (Qiu et al., 2003). In dopamine neurons, this mER signaling pathway may be involved in dopamine-mediated inhibition of prolactin secretion (Frawley and Neill, 1980). Although we targeted the POMC- and dopamine-rich areas of the mediobasal hypothalamus, this mER signaling pathway could be involved in numerous other homeostatic pathways yet to be determined.

The pharmacological characteristics of the hypothalamic mER appear to be different from estrogen receptor " $\mathrm{X}$," which is expressed in the cortex during development and after ischemic injury, is activated by $17 \alpha$-estradiol, and is not antagonized by ICI 182,780 (Toran-Allerand et al., 2002). However, the molecular identity of the hypothalamic mER is not known. Recently, an orphan GPCR (GPR 30) has been identified in breast carcinoma cell lines that binds estrogen with relatively high affinity, but ICI 182,780 stimulates adenylyl cyclase activity in SKBR3 cells that express GPR 30, GPR 30-transfected MDA-MB231 cells, and GPR 30-transfected HEK (human embryonic kidney) cells (Filardo et al., 2002; Revankar et al., 2005; Thomas et al., 2005). GPR 30 mRNA has been localized in the hypothalamus by in situ hy- b

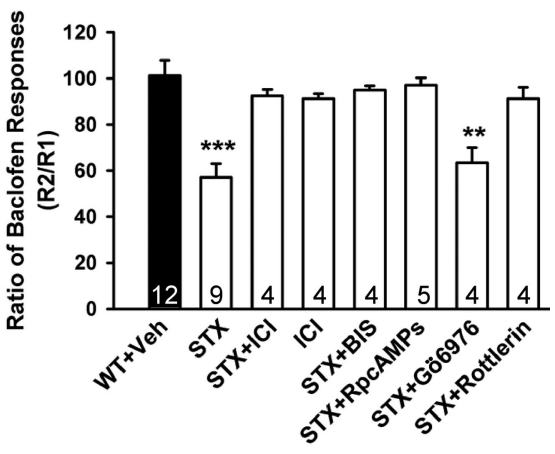

Figure 2. STX attenuation of the $\mathrm{GABA}_{\mathrm{B}}$ response depends on activation of PKC and PKA activation in hypothalamic arcuate (POMC) neurons. $\boldsymbol{a}$, Three representative traces of the baclofen response in the presence of STX (100 nM), STX and Rp-CAMPs (200 $\mu \mathrm{M})$, or STX and rottlerin $(5 \mu \mathrm{m})$ in arcuate neurons from ovariectomized guinea pigs are shown. $\boldsymbol{b}$, Bar graphs summarizing the 列

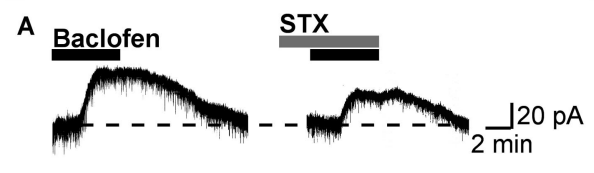

$20 \mathrm{pA}$

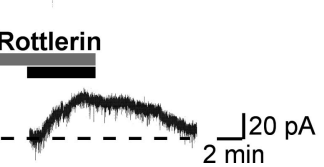

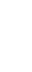


a

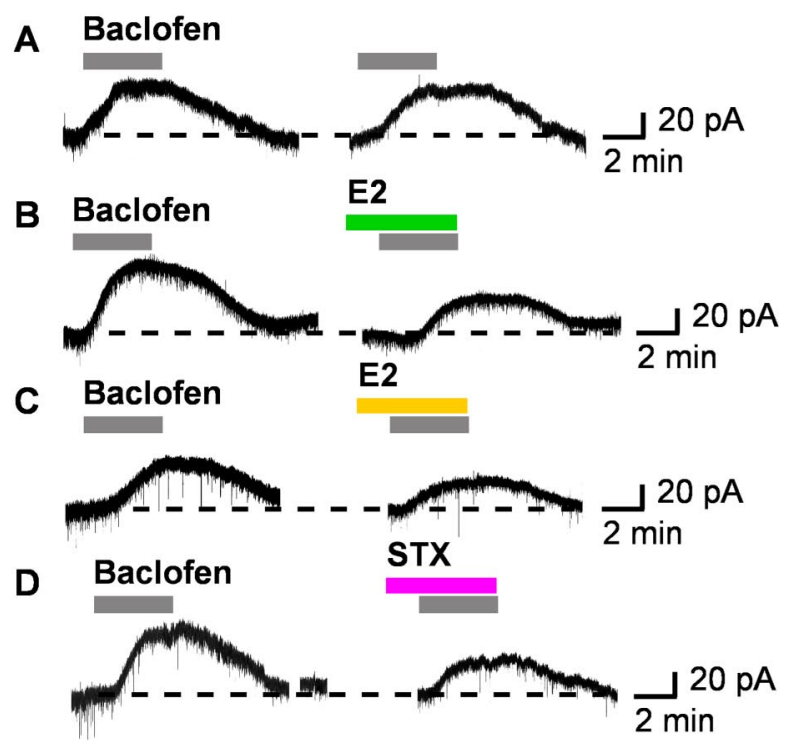

b

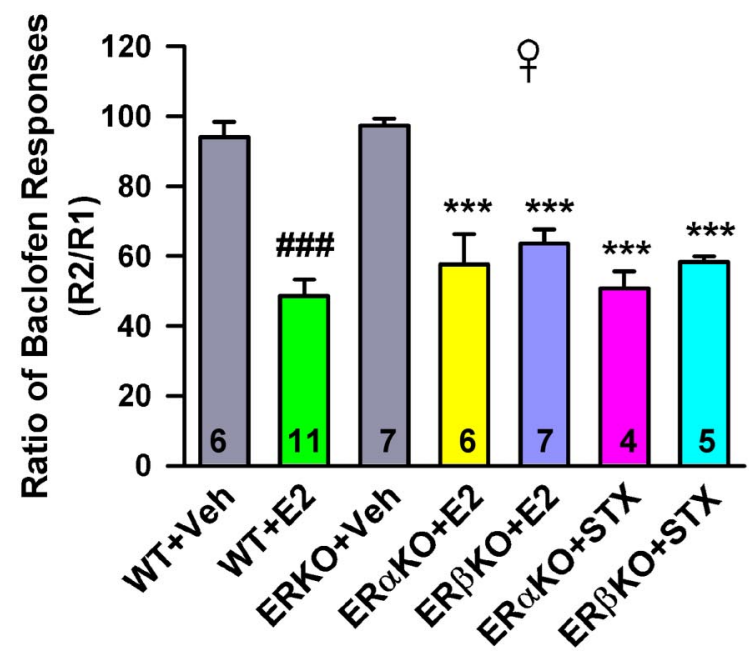

C
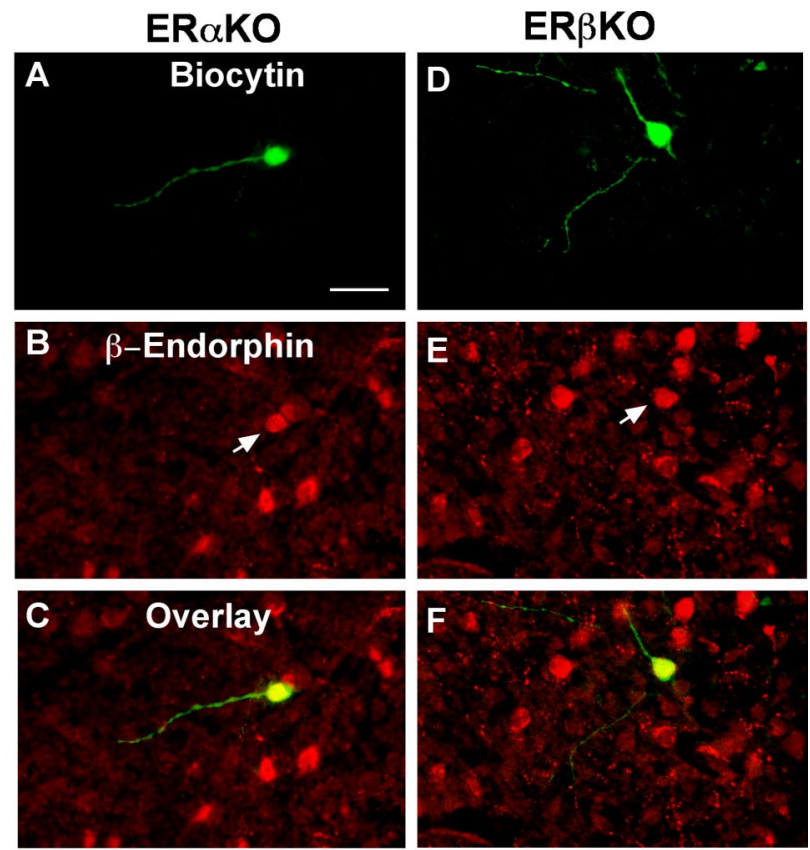

d

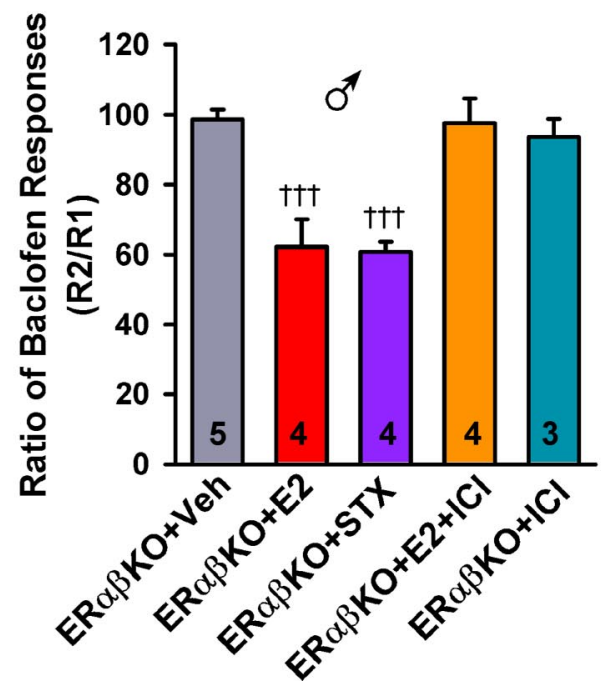

Figure 3. $E_{2}$ and STX rapidly attenuated the baclofen response in hypothalamic arcuate (POMC) neurons in wild-type and ER $\alpha K 0, E R \beta K O$ and ER $\alpha \beta K O$ mice. $a$, Experiments were conducted as described in the Materials and Methods. Four representative traces of the baclofen response in the presence of vehicle, $E_{2}(100 \mathrm{nM})$, or STX (100 nM) in arcuate neurons from wild-type $(\boldsymbol{A}, \boldsymbol{B})$ and ER $\alpha K O(C, D)$ mice are shown. $\boldsymbol{b}$, Bar graphs summarizing the effects of $\mathrm{E}_{2}$ or STX in arcuate (POMC) neurons from ovariectomized, wild-type, ER $\alpha$ KO, and ER $\beta K O$ mice. $\mathrm{E}_{2}$ and STX (100 nM) rapidly attenuated the outward (GIRK) current induced by the GABA $A_{B}$ receptor agonist baclofen in arcuate (POMC) neurons from ovariectomized wild-type (C57BL/6), ER $\alpha$ KO, and ER $\beta K 0$ mice. Bars represent the mean \pm SEM. ${ }^{\# \#} p<0.001$, $E_{2}$-treated wild-type group versus vehicle (Veh) wild-type control; ${ }^{* * *} p<0.001, \mathrm{E}_{2}$ - or STX-treated ER $\alpha K 0$ or ER $\beta K O$ groups versus vehicle ERKO control. The data for the ER $\alpha K O$ and ER $\beta K O$ control responses were combined in one bar graph. $\boldsymbol{c}$, Double labeling of POMC neurons that responded to STX from ER $\alpha$ KO $(\boldsymbol{A}-\boldsymbol{C})$ and ER $\beta K O(D-F)$ mice. Arcuate neurons were filled with biocytin during the whole-cell recording. $A, D$, Biocytin-streptavidin-Cy2 labeling of two small pyramidal arcuate neurons. $B, E$, Immunocytochemical staining of $\beta$-endorphin in the same neurons (arrow). $\boldsymbol{C}$, overlay of $\boldsymbol{A}$ and $\boldsymbol{B} ; \boldsymbol{F}$, overlay of $\boldsymbol{D}$ and $\boldsymbol{E}$. Nineteen of the 46 responsive neurons (41\%) were identified as $\beta$-endorphin neurons. Scale bar: $\boldsymbol{A}-\boldsymbol{F}, 20 \mu \mathrm{m}$. $\boldsymbol{d}$, Bar graphs summarizing the effects of $\mathrm{E}_{2}, \mathrm{STX}$, or ICl 182,780 in arcuate (POMC) neurons from male ER $\alpha \beta$ KO mice. $\mathrm{E}_{2}$ and STX (100 nM) rapidly attenuated the outward (GIRK) current induced by the $\mathrm{GABA}_{B}$ receptor agonist baclofen, which was antagonized by ICI. ICl alone had no effect. Twelve of the $20(60 \%)$ neurons were identified as POMC neurons. Bars represent the mean \pm SEM. ${ }^{+t+} p<0.001, \mathrm{E}_{2}$ - or STX-versus vehicle-treated cells from $E R \alpha \beta K O$ mice.

ningham et al., 1998). In addition, the slope conductance of the G-protein-gated inwardly rectifying $\mathrm{K}^{+}$channel (GIRK) current is not altered, indicating that $\mathrm{E}_{2}$ (STX) is not acting directly on the channel pore (Lagrange et al., 1997; Qiu et al., 2003). However, we know that the signaling pathways of $\mathrm{E}_{2}$ (STX) and serotonin are in parallel but convergent pathways in these same neurons (Qiu et al., 2005). Indeed, the serotonin $5-\mathrm{HT}_{2 \mathrm{C}}$ receptor is also $\mathrm{G} \alpha_{\mathrm{q}}$-coupled and impinges on the $\mathrm{GABA}_{\mathrm{B}}$ signaling pathway in POMC neurons (Qiu et al., 2005), and the expression of 5- $\mathrm{HT}_{2 \mathrm{C}}$ receptors is critical for maintaining energy homeostasis (Tecott et al., 1995; Heisler et al., 2002). Interestingly, serotoninergic drugs (selective serotonin reuptake inhibitors) and $\mathrm{E}_{2}$ are effective in alleviating postmenopausal symptoms in women (Stearns et al., 2002). It may be that $\mathrm{E}_{2}$ and serotonin (via mER and $5-\mathrm{HT}_{2 \mathrm{C}}$ receptors, respectively) synergize to regulate energy metabolism in postpubertal females.

In summary, our findings indicate that the mER in hypothalamic arcuate (POMC) neurons is distinct from ER $\alpha$ or ER $\beta$. 

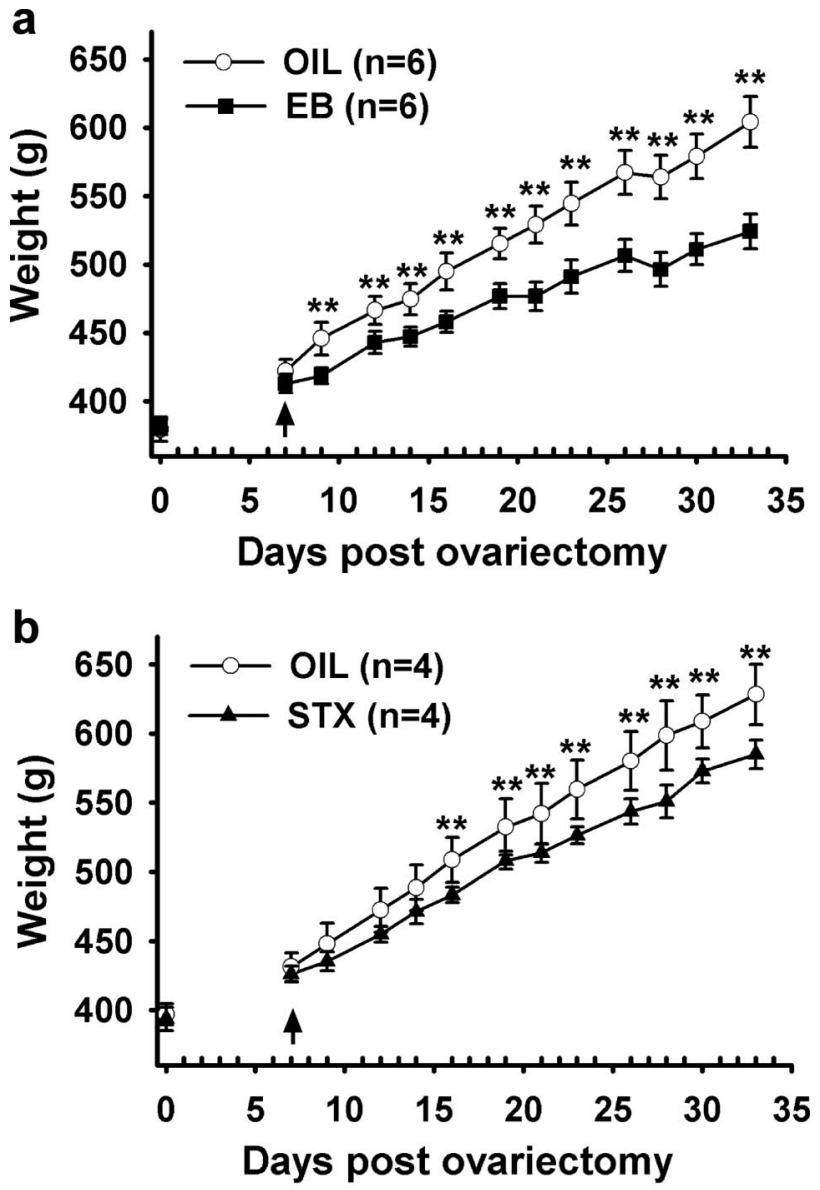

C

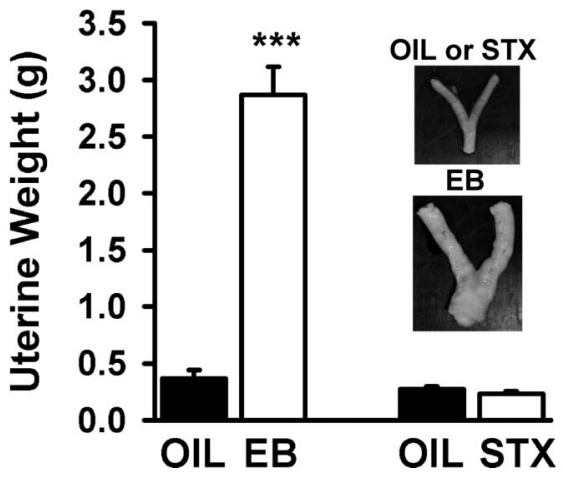

Figure 4. Estrogen $(\boldsymbol{a})$ and STX $(\boldsymbol{b})$ significantly attenuate the body weight gain in female guinea pigs after ovariectomy. The female guinea pigs were ovariectomized (on day 0 ) and allowed to recover for 1 week before being given bi-daily subcutaneous injections of oil (OIL), estradiol benzoate (EB), or STX (see Materials and Methods). A two-way ANOVA (repeated measures) revealed an overall significant effect of both estrogen and STX ( $p<0.001)$, and post hoc Newman-Keuls analysis revealed daily significant differences between estrogen and oiltreated, and STX and oil-treated groups $\left({ }^{* *} p<0.01\right)$. Bars represent the mean \pm SEM of six and four animals per group for estrogen and STX treatment, respectively. c, Uteri are enlarged after estradiol, but not after STX or oil-vehicle treatment (inset). After the treatment period, the uteri of the guinea pigs were harvested and examined. There was a significant increase in uterine size after $E B$, compared with oil-vehicle or STX treatment. Bar graphs represent mean uterine weights. ${ }^{* *} p<0.001$, EB versus oil-treated females; $n=6$ guinea pigs/group.

Moreover, we have identified a nonsteroidal compound, STX, as a selective ligand for the mER. STX is significantly more potent then estrogen in activating cellular cascades that lead to desensitization of $\mathrm{GABA}_{\mathrm{B}}$ and $\mu$-opioid receptors in hypothalamic arcuate neurons that are involved in the control of homeostasis.
The fact that $\mathrm{E}_{2}$ and STX are fully efficacious in activating this signaling pathway in double-estrogen receptor knock-out mice is further proof for the existence of a novel mER that is involved in critical physiological processes. In addition to its role in energy homeostasis, this hypothalamic mER may also be involved in temperature regulation, circadian rhythms, stress responses, and motivated behaviors.

\section{References}

American College of Obstetricians and Gynecologists (2005) Body mass index and insulin resistance. Obstet Gynecol 104:5s-10s.

Blaustein JD (1994) Estrogen receptors in neurons: new subcellular locations and functional implications. Endocr J 2:249-258.

Butera PC, Czaja JA (1984) Intracranial estradiol in ovariectomized guinea pigs: effects on ingestive behaviors and body weight. Brain Res 322:41-48.

Cone RD (2005) Anatomy and regulation of the central melanocortin system. Nat Neurosci 8:571-578.

Cunningham MJ, Fang Y, Selley DE, Kelly MJ (1998) $\mu$-Opioid agoniststimulated $\left[{ }^{35} \mathrm{~S}\right] \mathrm{GTP}$ gammaS binding in guinea pig hypothalamus: effects of estrogen. Brain Res 791:341-346.

Czaja JA, Goy RW (1975) Ovarian hormones and food intake in female guinea pigs and rhesus monkeys. Horm Behav 6:329-349.

Dupont S, Krust A, Gansmuller A, Dierich A, Chambon P, Mark M (2000) Effect of single and compound knockouts of estrogen receptors $\alpha(\mathrm{ER} \alpha)$ and $\beta(\mathrm{ER} \beta)$ on mouse reproductive phenotypes. Development 127:4277-4291.

Filardo EJ, Quinn JA, Frackelton Jr AR, Bland KI (2002) Estrogen action via the G protein-coupled receptor, GPR30: stimulation of adenylyl cyclase and cAMP-mediated attenuation of the epidermal growth factor receptor-to-MAPK signaling axis. Mol Endocrinol 16:70-84.

Fodor M, Delemarre-van de Waal HA (2001) Are POMC neurons targets for sex steroids in the arcuate nucleus of the rat? NeuroReport 12:3989-3991.

Frawley LS, Neill JD (1980) Effect of estrogen on serum prolactin levels in rhesus monkeys after hypophyseal stalk transection. Biol Reprod 22:1089-1093.

Heisler LK, Cowley MA, Tecott LH, Fan W, Low MJ, Smart JL, Rubinstein M, Tatro JB, Marcus JN, Holstege H, Lee CE, Cone RD, Elmquist JK (2002) Activation of central melanocortin pathways by fenfluramine. Science 297:609-611.

Horvath TL (2005) The hardship of obesity: a soft-wired hypothalamus. Nat Neurosci 8:561-565.

Jobst EE, Enriori PJ, Cowley MA (2004) The electrophysiology of feeding circuits. Trends Endocrinol Metab 15:488-499.

Kelly MJ, Levin ER (2001) Rapid actions of plasma membrane estrogen receptors. Trends Endocrinol Metab 12:152-156.

Kelly MJ, Loose MD, Rønnekleiv OK (1992) Estrogen suppresses $\mu$-opioid and $\mathrm{GABA}_{\mathrm{B}}$-mediated hyperpolarization of hypothalamic arcuate neurons. J Neurosci 12:2745-2750.

Kelly MJ, Lagrange AH, Wagner EJ, Rønnekleiv OK (1999) Rapid effects of estrogen to modulate $\mathrm{G}$ protein-coupled receptors via activation of protein kinase A and protein kinase C pathways. Steroids 64:64-75.

Komesaroff PA, Sudhir K, Esler MD (1999) Effects of estrogen on stress responses in women. J Clin Endocrinol Metab 84:4292-4293.

Koob GF (1992) Drugs of abuse: anatomy, pharmacology and function of reward pathways. Trends Pharmacol Sci 13:177-184.

Krege JH, Hodgin JB, Couse JF, Enmark E, Warner M, Mahler JF, Sar M, Korach KS, Gustafsson JÅ, Smithies O (1998) Generation and reproductive phenotypes of mice lacking estrogen receptor beta. Proc Natl Acad Sci USA 95:15677-15682.

Lagrange AH, Rønnekleiv OK, Kelly MJ (1994) The potency of $\mu$-opioid hyperpolarization of hypothalamic arcuate neurons is rapidly attenuated by $17 \beta$-estradiol. J Neurosci 14:6196-6204.

Lagrange AH, Wagner EJ, Rønnekleiv OK, Kelly MJ (1996) Estrogen rapidly attenuates a $\mathrm{GABA}_{\mathrm{B}}$ response in hypothalamic neurons. Neuroendocrinology 64:114-123.

Lagrange AH, Rønnekleiv OK, Kelly MJ (1997) Modulation of G proteincoupled receptors by an estrogen receptor that activates protein kinase A. Mol Pharmacol 51:605-612.

McEwen BS, Alves SE (1999) Estrogen actions in the central nervous system. Endocr Rev 20:279-307. 
Milewicz A, Bidzinska B, Mikulski E, Demissie M, Tworowska U (2000) Influence of obesity and menopausal status on serum leptin, cholecystokinin, galanin and neuropeptide Y levels. Gynecol Endocrinol 14:196-203.

Milewicz A, Tworowska U, Demissie M (2001) Menopausal obesity-myth or fact? Climacteric 4:273-283.

Murphy KG, Bloom SR (2005) Peripheral influences on central melanocortin neurons. Peptides 26:1744-1752.

O’Dowd BF, Nguyen T, Marchese A, Cheng R, Lynch KR, Heng HH, Kolakowski LFJ, George SR (1998) Discovery of three novel G-proteincoupled receptor genes. Genomics 47:310-313.

Qiu J, Bosch MA, Tobias SC, Grandy DK, Scanlan TS, Rønnekleiv OK, Kelly MJ (2003) Rapid signaling of estrogen in hypothalamic neurons involves a novel $\mathrm{G}$ protein-coupled estrogen receptor that activates protein kinase C. J Neurosci 23:9529-9540.

Qiu J, Bosch MA, Rønnekleiv OK, Kelly MJ (2005) Convergence of membrane estrogen receptor and serotonin $5 \mathrm{HT} 2 \mathrm{~A} / \mathrm{C}$ receptor signaling in hypothalamic neurons. Soc Neurosci Abstr 31632.5.

Revankar CM, Cimino DF, Sklar LA, Arterburn JB, Prossnitz ER (2005) A transmembrane intracellular estrogen receptor mediates rapid cell signaling. Science 307:1625-1630.

Rønnekleiv OK, Kelly MJ (2005) Diversity of ovarian steroid signaling in the hypothalamus. Front Neuroendocrinol 26:65-84.

Saper CB, Chou TC, Elmquist JK (2002) The need to feed: homeostatic and hedonic control of eating. Neuron 36:199-211.

Sherwin BB (2002) Estrogen and cognitive aging in women. Trends Pharmacol Sci 23:527-534.

Shughrue PJ, Lane MV, Merchenthaler I (1997) Comparative distribution of estrogen receptor- $\alpha$ and $-\beta$ mRNA in the rat central nervous system. J Comp Neurol 388:507-525.
Sodersten P, Bergh C, Ammar (2003) Anorexia nervosa: towards a neurobiologically based therapy. Eur J Pharmacol 480:67-74.

Stearns V, Ullmer L, Lopez JF, Smith Y, Isaacs C, Hayes DF (2002) Hot flushes. Lancet 360:1851-1861.

Stearns V, Johnson MD, Rae JM, Morocho A, Novielli A, Bhargava P, Hayes DF, Desta Z, Flockhart DA (2003) Active tamoxifen metabolite plasma concentrations after coadministration of tamoxifen and the selective serotonin reuptake inhibitor paroxetine. J Natl Cancer Inst 95:1758-1764.

Tecott LH, Sun LM, Akana SF, Strack AM, Lowenstein DH, Dallman MF, Julius D (1995) Eating disorder and epilepsy in mice lacking 5-HT2c serotonin receptors. Nature 374:542-546.

Thomas P, Pang Y, Filardo EJ, Dong J (2005) Identity of an estrogen membrane receptor coupled to a G-protein in human breast cancer cells. Endocrinology 146:624-632.

Tobias SC, Qiu J, Kelly MJ, Scanlan TS (2006) Synthesis and biological evaluation of SERMs with potent nongenomic estrogenic activity. Chem Med Chem 1:565-571.

Toran-Allerand CD, Singh M, Setalo Jr G (1999) Novel mechanisms of estrogen action in the brain: New players in an old story. Front Neuroendocrinol 20:97-121.

Toran-Allerand CD, Guan X, MacLusky NJ, Horvath TL, Diano S, Singh M, Connolly Jr ES, Nethrapalli IS, Tinnikov AA (2002) ER-X: a novel, plasma membrane-associated, putative estrogen receptor that is regulated during development and after ischemic brain injury. J Neurosci 22:8391-8401.

Wilson ME, Mook D, Graves F, Felger J, Bielsky IF, Wallen K (2003) Tamoxifen is an estrogen antagonist on gonadotropin secretion and responsiveness of the hypothalamic-pituitary-adrenal axis in female monkeys. Endocrine 22:305-315. 